\title{
GERMANICUS REVISITED-AND REVISED?
}

\section{Jo-Marie Claassen (University of Stellenbosch)}

This paper sets out to discuss a dramatic reworking of some chapters of Tacitus' Annales in the light of a recently discovered inscription containing the text of a decision of the Roman Senate, taken in the year A.D. 20.

That Tacitus composed like a dramatist was first mooted by Mendell in 1935, in an analysis of, among others, the first eight books of Tacitus' Annales. ${ }^{1}$ This theory has been variously explored and fairly consistently shown to be tenable (Petersmann 1993, Cizek 1993, Billerbeck 1991, Fabbrini 1986, Wille 1983). ${ }^{2}$ Long before Mendell, Shakespeare's contemporary Ben Jonson, like the sculptor Michelangelo discovering 'the angel in the stone', exploited the dramatic potential of Ann. 4-8 in his five-act drama Sejanus, His Fall. As a play, it did not work for its contemporary audience, and it has seldom been performed. Its merit as a literary reworking of an interesting era has been variously extolled and criticized. ${ }^{3}$ Sejanus depicts the career of its eponymous anti-hero on a stage cluttered with characters. The drama entails a powerful analysis of the problem of corruption inherent in a despotic regime in a manner that touched the nerve of a despotic monarch (James I, who had shortly before the first production of the play tried Sir Walter Raleigh for treason) to the

1 Mendell (1935) discusses the Prologue to the Annales as dramatic (pp.9-10) and then concentrates on what he terms the "drama of Tiberius" in which Germanicus, Piso and Seianus in turn are used as foils to highlight the chief protagonist (pp.11-17) and the later "tragedy of Nero" (pp.18-28-see Muller 1994). In the unfolding of the Tiberius story two concepts are deemed by Mendell to stand out almost as dramatis personae (p.17): first libertas, represented by a "group". Piso, Arruntius and Gallus (p.14) and next the "progress of oppressive legislation" linked with the career of Seianus (p.17). What Mendell has termed successive "acts" within a greater drama have provided material for two distinct plays, those under discussion.

Wille's (1983) narratological analysis of the Annales may be studied to discern the schematic design of what Mendell termed 'the tragedy of Tiberius'. Tacitus did not, of course, here write dialogue. By 'dramatic' one should understand 'selection and arrangement', even 'fictionalization' of material. Cf. Petersmann 1993:15-18 on Tacitean intentional 'fictionalization' of facts as tendentious signal; Koves-Zulauf 1992 on dramatic techniques in the Dialogus de oratoribus, where Julius Secundus, almost the most famous orator of his time, acts as a non-speaking lay figure, thereby emphasizing the degree to which oratory has degenerated under Augustus; Strocchio 1992 on the dramatic effect of silence in relation to both Tiberius and his various victims. Schunck (1955:132-134) discusses in the diction of the dramatic critic the 'roles' Tacitus ascribes to Livia in her relationship with Agrippina Maior. Wiseman (1994) conjectures that early Roman historiography arose from folk drama.

See Ayres' (1990) Introduction to the Revels Plays edition, which offers some good facsimiles of the Quarto edition of 1605, with Jonson's own extensive marginal notes referring to his sources (Plates 1 and 2). Contemporary and eighteenth-century criticism centred largely on the impossibility of seeing Seianus an a good man flawed according to Aristotelian criteria, modern criticism on its 'inferiority' when measured against Shakespeare's Roman plays, his (over-)simplification of the complex characters of Tiberius and his non-solution of the opposition of the ideas of Fortune versus free will which pervade the play. Ayres himself gives a balanced critical overview of Jonson's "flawed masterpiece" (sic) (1990:22-28). 
point that its published version had to be censored by its author, so Ayres (1990:1622). Yet neither Jonson's intentions with his Roman drama, nor its topicality, nor his close adherence to his ancient sources, are the topics here. Rather, the paper focuses on a far more successful reworking of the Tacitean dramatic potential inherent in Ann. 1-3.

The non-Afrikaans-speaking world may perhaps be unaware that the story of Cnaeus Calpurnius Piso's role in the death of Germanicus was turned into a cohesive play by the Afrikaans poet N.P. van Wyk Louw, in his metrical drama Germanicus (1956), which is largely based on the chapters of the Annales immediately preceding Jonson's source. It is generally considered to be a highlight in Afrikaans literary development, and the present author, for one, considers that it deserves international attention. Hence this discussion in English.

Louw chose to limit his drama to 'the tragedy of Germanicus', ending with the hero's death. Louw's debt to Tacitus and others was carefully spelled out by P.J. Conradie (1974) in Die gebruik van antieke bronne in Van Wyk Louw se Germanicus. Earlier (1972) Conradie had analyzed Louw's use of imagery in the drama. Conradie's even earlier (1966) study guide for high school and undergraduate students (a so-called Blok Boek) elucidates all aspects which may be unclear to a non-classical readership or audience: a basic definition of 'Drama' is followed by a brief historical resume and a detailed narration of the eight scenes which comprise the play. ${ }^{4}$ This is followed by an analysis of the theme and dramatic structure (or articulation of the thought-the Afrikaans word is 'bou') of the drama. Conradie also placed the work in the context both of Louw's oeuvre and of Afrikaans literature, ending with an overview and evaluation of critical responses up to the date of his study guide. 5 Since then studies have appeared by Piek (1971), Pretorius (1972), Kannemeyer (1978) and more recently, Olivier (1992), whose analysis of Louw's intellectual contribution to South African self-awareness can serve as clarification of aspects of Louw's ambivalence about the relationship between intellectual and political freedom, which is one of the contemporary issues he highlights in the drama.

It may be argued that no more need be said about this drama, written in a language which on the world's stage may be doomed to increasing obscurity. There are, however, a variety of reasons why a new discussion is fitting in a volume dedicated to Conradie. On the obvious level, he, too, is an Afrikaans-speaking author whose writings are worthy of international dissemination. He is the doyen of South African researchers on the classical tradition in drama. 6 On the academic

4 There are indications that Louw initially planned a formal five-act play (Antonissen 1962:180).

5 I follow Conradie's (1966) judgement of the critics, some of whom clearly could have benefited by the insights afforded by greater familiarity with Louw's ancient sources. See my Bibliography below, which lists most of the critics, but not always the same editions evaluated by Conradie, who features Grové's first edition (1958) and the published version (1962) of Brink's dissertation (1959).

6 More personally, it was under his tutelage that the present author first read the Tacitean passages involved, in a singularly fruitful year of graduate study. 
level, however, perhaps the most urgent reason to revisit both the ancient historian and the modern dramatist has been the sensational discovery in Spain (ancient Baetica) of several large fragments of the Senatusconsultum de patre Pisone, which was promulgated throughout the empire after the death of Germanicus and subsequent trial of Piso. These documents are still in the process of publication, and cannot be studied at length or quoted in full by outsiders. I must admit a debt to an Oxford colleague, whose reportage of the find sparked my interest in revisiting the play. 7 The question I wish to pose, is not "Do these documents force us into reappraisal of Tacitus' Ann. 1-3?" - but rather, "If Van Wyk Louw had been able to consult these sources, would his portrayal of the clash between Germanicus and Piso have been different?"

Tacitus' portrayal of Germanicus is generally conceded to be problematic, and critical opinion of the intention of the historian ranges from "wholly positive" 8 to "ambiguous" (Devillers 1993), to strongly negative (Shotter 1968; Ross 1973). The best recent discussion of the problem is that of Pelling (1993) who construes Tacitus' characterization of Germanicus as "consistently inconsistent" in an intentional series of contrasts with other key figures: with Tiberius, with Arminius, and with Piso himself. ${ }^{9}$ Van Wyk Louw's 'Germanicus', as a character, on the surface appears to coincide with the Germanicus of early critics' positive interpretation (which Syme (1958:418) derides) of Tacitus' judgement of the hero. A more careful reading reveals many of the same uncertainties that face Tacitean critics, and gives us similar insights. Louw's Germanicus is not wholly admirable. What is perhaps most inconsistent and problematical about the character is exactly what is most Tacitean. We must deduce that Louw as classicist himself was dubious about Tacitus' intentions with this character. More of this below.

Van Wyk Louw's Germanicus as a drama, like its Elizabethan counterpart, has its own problematic areas. It was staged for the first time in the Western Cape in 1956, the year of its publication ${ }^{10}$ and again at Stellenbosch in 1971. It has since frequently been set by various examining bodies as compulsory reading for the SA Matriculation examinations in Afrikaans literature. It may be assumed that the average young reader comes to the text with very little knowledge of the historical

7 Dr Barbara Levick, of St Hilda's College, who introduced an interesting discussion on the topic at an Ancient History Workshop at the University of Cape Town in October 1993, and who has in subsequent conversations further filled in details for me. The fragments are in the possession of the Spanish government, and certain strict protocols have to be adhered to in any analysis of the documents, which are still in preparation by Professor Werner Eck, of Glotz, and his Spanish colleagues, Professors Antonio Caballos and Fernando Fernandez, both of Seville.

8 Some of the earlier critics, quoted by Syme (1958:418), who sees Tacitus' laudation of Germanicus as "grotesque in its disproportion" (1958:498). For the critical tradition see Ross 1973:209-10; Pelling 1993.

9 The actions of Piso and Plancina in Ann. 2.78-80 mirror those of Germanicus and Agrippina in 1.33-36.

10 Kannemeyer (1978:408) traces its genesis through 1944-1948, as the byproduct of an uncompleted drama based on the life of Caligula. Parts had been published as early as 1952 . 
background, as did, presumably, the larger part of each audience at its various productions. Its structure is unconventional, as it comprises eight 'scenes' and not the more conventional five acts (Kannemeyer 1978:408-410). The reception of, or reaction to, the drama of both comparatively ignorant high school students and the intelligent layman is a point of discussion within the Afrikaans literary world. Van Wyk Louw's poetry is forceful and much admired. Yet as a play Germanicus is considered too static-it does not 'work' as a dramatic production, although it is considered eminently playable in a non-visual medium, the radio.11 Grove (1965:185) considers the work as a "dramatic poem" rather than a "play", whereas Brink (1959:1-25) argues for a reappraisal of both Louw and Shakespeare in terms of a new definition of the essence of drama: that its hero must serve as defender of order in its conflict with chaos. Antonissen (1962:180-185) speaks of a "sublime dispute", and labels the play as essentially a "psychological idea-drama". Piek (1971) and Pretorius (1972:30-44, 63) have no problem construing Louw's Germanicus as an Aristotelian hero, yet Piek finds it to be impossible for the ordinary person to identify with Germanicus' inner passivity and his outward certainty of his own taint-free clarity of spirit. For Pretorius (1972:45) the requisite "fatal flaw" is the character's concentration on his inner life, and consequent passivity. Kannemeyer (1978:411-412) accepts Germanicus' passive acceptance of the inevitable as an essential element of his character, and deems the "true tragedy" to lie in the sufferings of Tiberius, Piso and the other characters, where there is no chance of any redemption.

The same insistent questions arise whether the drama is watched or read: why does Van Wyk Louw's Germanicus the man talk so much about 'freedom' and 'simplicity', while he seems to do nothing about either, 12 and why does the friendship between Louw's characters Piso and Germanicus turn sour? A literary work is such because its author wills it so, even in an ostensibly 'historical' drama, working with 'facts'. As Conradie (1974:34) points out, the dramatist selects and rearranges material in order to portray an issue to which his audience can relate-in other words, literature does or should portray the universal. The interaction of Louw's characters portrays the type of conflict that the author wishes to explore, the relationship between intellect and action, self-control and power (Pretorius 1972:2830, 34-56). An esoteric and largely academic question about the potential for influence of the Senatusconsultum de patre Pisone on Louw's drama can be

11 Antonissen (1962:8) waxes lyrical about the profound impression a broadcast version made on him in early 1950. In this aspect it is 'more dramatic' than Jonson's Sejanus, which has more frequently been treated as 'reading matter' than it was ever staged (Ayres 1990:37-40).

12 Antonissen (1962:181) defends this passivity in the hero as a sign of intense cerebration, but notes (p.184) that Louw's portrayal of Agrippina's increasing passivity is psychologically implausible. Here, too, the parallel with Jonson's drama is significant: the 'Germanicans' ('republicans', or harkers back to the old order) are seen to be too static. The fault may be traced to a common source: Tacitus' portrayal of the 'heroic faction', which, in Mendell's (1935:14) view, acts as a composite heroic foil to Tacitus' ultimate villain, Tiberius. 
rephrased to include and expand on the kind of non-academic questions potentially posed by both immature readers and the members of a notional, intelligent, but non-classical, 'ideal audience'-could or would Van Wyk Louw's portrayal of protagonist and antagonist, and perhaps also of the issues involved, have been enriched or clarified, if the modern playwright had had access to the document in question?

For my wider readership, what follows is a short resume of Louw's drama, which moves, in a series of eight 'scenes' from the military front in Germania at the time of Augustus' death in A.D. 14, to Rome at an unspecified date, and to the near east, where it culminates in the death of Germanicus in 19. Historical events are in some cases collapsed and conflated, to suit the author's artistic purpose (Conradie 1974:35, 56-58).

Scene One conveys the tone of Tacitus' narrative, rather than the factual events, of Ann. 1.31-37. Some Roman officers, one of them Germanicus muffled in a disguising military cloak, approach a campfire, where soldiers are discussing the recent demise of Augustus. The soldiers are keen to rebel. Piso is portrayed as the champion of the republican ideal who urges the soldiers to declare Germanicus imperator. He argues that military power precedes the accession to civil power:

Die man wat heers in Rome, moet hier heers,

en wie òns-ek en julle-nie vertrou nie

wip gouer uit die saal as hy geklim het.

(Who rules in Rome must rule here too, and he whom we-I and you all-don't trust

drops faster from his saddle than he got on.) (p.12) ${ }^{13}$

Germanicus throws off his cloak and stands forth to repudiate the suggestion. Agrippina appears and upbraids the soldiers, who lapse into silence, all except one. He is summarily killed by the general. Germanicus will allow no talk of rebellion, but calls his men to arms, for a sweep to the north.

In the second scene a discussion in the tent of Piso about the growing probability that Germanicus will succumb to the lure of 'Caesarian' power politics, a minor character, 'Lucius' (not attested in the sources, but apparently created by the poet for the purposes of his plot) expresses preference for death rather than the loss of his republican dream and the fall of his idol. This follows on Piso's suggestion that Lucius may be called upon to eliminate their potentially disappointing champion. From the dialogue we learn that Germanicus inclines more to thought than action, and that Piso, a man of action, "sees life plainly, but sees it whole":

13 References will hereafter be to page numbers in the original edition, Louw (1956). Freely-rendered translations (by the present author) will attempt to convey the play's tone, its slightly archaic diction and its rhythmic effects rather than the precise words or exact metrical patterns of the original. 
Lucius: Jy't my leer edel dink, jy't my leer leef in die hoë eenvoud wat jou eie is.

(You trained my noble thoughts, you taught me live in that high simplicity so much your own.) (p.25.)

Lucius' words appear to strengthen Piso's resolve to champion freedom at any cost, and he decries 'love', 'friendship' and 'humanity' as lesser things than 'honour' and 'duty' (p.25).

Scene Three is a masterpiece of conjecture: like the speeches in Thucydides or Tacitus, it portrays 'what might have been said'; in this case, what might have been said in the tent of Agrippina during consecutive conversations with her female attendant, her physician and her husband. Agrippina's fears are virtually ignored by an intellectual Germanicus, more interested in his poetic reworking of Aratus' text on astronomy than in either the possibility of his untimely death or the invitation to usurp imperial power. Agrippina urges him to dare to rule in Rome. Here she is both the strong woman depicted by Tacitus in Ann. 1.40-41 (cf. Santoro L'Hoir 1994), and the conventionally fearful wife:

Gryp watter kant ek wil, ek vat alleen iets koel en glansends. Hierdie rus van jou: vannag-Moet jy nie vréés nie? Ja, die vrees, dis goed en menslik: hou dit by jou hart.

Whatever way I try to reach, I only touch this coolly gleaming thing. This quiet rest of yours tonight-Should you not fear? Yes, this fear, it's good and human: keep it near your heart.) (p.32)

In Scene Four Louw uses the 'Bodenbericht' technique to convey the gist of Ann. 1.55-71, Germanicus' victories over the Chatti and Cherusci. Piso's reaction to Germanicus' sorrow over the death in action of Lucius works as a device to illustrate the growing tension between the man of action and the man of thought and feeling. The pregnant wife and father-in-law of Arminius (here 'Herman') are brought in. The father Segestes is all ingratiating subservience to Rome, but his daughter Thusnelda stands proudly aloof. She works as a prophetic figure, presaging the fate of all members of the imperial family: there is no escape from the cloying obligations of power. She addresses Germanicus:

Ek ken U nie ... miskien miskien is $U$ selfs edel: maar die Ryk gebruik ook edeles vir sy werk om die sagte woorde nà die gruweldaad, nà die neerslaan en corrompeling te sê.

Selfs as U sag praat, praat die blinde mag.

(... I don't know You ... perhaps, perhaps You may be noble: 
but nobles also bow to serve

to give soft names to horror-deeds,

and after carnage and fell battery to speak.

Your softest words reflect blind might.) (p.45)

The woman is removed and Germanicus hands over gifts to his closest friends: Piso is given his sword. A letter from Tiberius recalls Germanicus to Rome, and his friends urge action. Another minor character, Marcus, commits suicide out of despair at Germanicus' loyal refusal to move against Tiberius. Agrippina is aware of impending doom. "Die skedel groei uit ons" ("A scull sprouts out of us") (p. 57), she says.

Two scenes in Rome set the tone for the action in the last part of the drama: in Scene Five, again a dramatic figment of the author, four women feature; three are contrasted. Livia is portrayed as monstrous, wrapped in blind hatred for all around her, including her son, whom she, however, vows still to protect (p.67). The attitude of the enslaved Thusnelda reflects the spirit of Tacitus' grudging admiration for the noble savagery of German women in his Germania. Against both Agrippina is matronly and noble in her attempt to protect the hapless captive. The fourth woman, Plancina, wife of Piso, Livia's confidante when the scene opens, remains a virtual lay figure, subservient to her evil patroness, and willing, albeit uncomfortably, to carry out her arbitrary command to stand up and measure herself against the German woman. Plancina's complaisance offers another view of the captive, who speaks of herself as no longer human, but as the embodiment of hatred (p.61). The scene ends with Livia's injunction to Plancina to be her "hands" when the latter accompanies her husband to the East in the entourage of Germanicus. Livia's physician will aid her on the way. We are left in no doubt that this way will be evil. Louw appears to subscribe unquestioningly to Tacitus' most negative opinions of the dowager. 14

The drunken and haunted Tiberius of Scene Six exhibits all the worst characteristics of the emperor as portrayed by both Tacitus and Suetonius. His consciousness of the monstrosity of power does not prevent his wielding such power to grim effect: the slave Clemens who had pretended to be the murdered Agrippa Postumus (whose death Tacitus designates the "first misdeed of the new regime", Ann. 1.6) is brought on, blinded and horribly maimed, and then taken off to suffer a predictably terrible death. This slave cannot recognize the passive Germanicus standing by horrified, and like the voice of Thusnelda, Clemens' voice becomes a voice of prophecy, predicting an early death for the unknown young man before him. Germanicus retreats further into dismayed silence when a "message to Germanicus" is given him to relay: that all had thought to find a saviour in the prince, but:

... hy ... hy vreet saam met hul uit die bak.

14 Documented and discussed by Santoro L'Hoir (1994: esp. 13-20). 
Neem jy die boodskap: sê "Die wêreld haat hom en glo hy's klein".

(... he ... he swills with them from the selfsame trough.

You take this message: say: "The world, it hates him and thinks he's small".) (pp.78-79)

Louw's Tiberius exhibits awareness of the many-headedness of the monster Power, but he has willingly accepted the burden of guilt, whether it be the need to sign a death warrant for a hundred slaves, or to suppress a revolt against his own power: he is trapped in a circle of violence: "So heers 'n mens, so dom, so gruwelik!" ("This is the way one rules, so blind, so pitiless!") (p.81).

An aspect of the problem of the author's portrayal of initial friendship between Piso and Germanicus and the gradual revulsion of Piso against his hero may be found in this scene: Livia comes to warn her son against Piso's potential for rebellion, indicates Plancina as her informant, and offers the latter's services in the East as a check upon her own husband. So Plancina does not share her husband's ideals. The complicity of Louw's Plancina presages the claim of her loyalty to Livia in the Senatusconsultum de patre Pisone, of which more below. Louw, however, highlights a dimension which the document vigorously denies: his Plancina will be the purveyor of the poison.

During the course of this episode it becomes abundantly clear that no love is lost between Tiberius and his mother, but that they are inextricably tied together; in this Louw is strangely un-Tacitean. The scene closes with Livia's explanation to Plancina that she never knows, can only guess, what Tiberius intends, and that the two of them must try to carry out what they think are his wishes: "ons, die is sy hande / wat deur ' $n$ vreemde kwaal so los is van sy hart" ("... we, we are his hands / which by some quirk are severed wholly from his heart") (p.88).

The action of the last two scenes takes place in the East. Scene Seven stages the events of Ann. 2.57, the feast at which the king of the Nabateans offered his Roman visitors golden crowns. Germanicus accepts his gift as a gesture of courtesy, but Piso rejects his with contumely. Germanicus is hesitant, clearly ill. Piso is strong, and violent in his reactions. After the Easterners have withdrawn, there is some discussion among the Romans of Germanicus' ailment and the possibility that he is systematically being poisoned. Agrippina appears concerned, Plancina angry at the insinuation of her complicity in Germanicus' illness, and the implication that Livia and Tiberius are involved. Then all leave, and Germanicus and Piso talk. Each complains of the other's behaviour. The contrast between the two is clear: Piso is the staunch republican to whom trappings of royal power are anathema: he does not understand diplomacy and accuses Germanicus of having succumbed to the lure of the East:

Germanicus, jy's jonk-oud, swak en slap.

Hier in die Ooste het jy week geword ... 
Jy't hier artiest geword.

(Germanicus, you're young-old, weak and limp.

Here in the East you have gone too soft, ...

...

You're now a dilettante.) (p.97) 15

Germanicus' complaint is about Piso's abuse of his power as local governor, as described by Tacitus in Ann. 2.55, 57 and 69, and spelled out at Piso's trial. 16 Louw's Piso accuses Germanicus of reluctance to uphold Roman control, and finally tries to manipulate him into action against Tiberius with a promise to detect and prevent the poisoning which is sapping the prince's strength, even if it should mean the death of his own wife. Germanicus' cosmic vision of the insignificance of human action against the sweep of the universe translates into a realization of his inability as well as his reluctance to act. He indignantly repudiates Piso's offer. Like his young friend Lucius, he will not be untrue to old loyalties. His choice is certain death, rather than rebellion against Tiberius, and the scene ends with a formal renuntiatio amicitiae before witnesses, and Germanicus abjures all further intimacy with Piso. 17

In the last scene, set near Antioch on the Orontes, Germanicus' officers discuss the reaction of the local population to the illness of their general. Louw's emphasis on Eastern elements in the last part of the drama is generally interpreted as his recognition of a changing world-order and of the rise of Christianity as an Eastern religion that brought about the change. ${ }^{18} \mathrm{~A}$ dying Germanicus repeatedly enquires about the doings of his erstwhile friend. He then admits to his presence a muffled stranger, on receipt of a token-the sword he gave to Piso in Germany. Piso enters. Their last conversation is essentially a recapitulation of the immovability of the stance of each protagonist, and the inevitability of their fatal clash. Piso dominates the conversation in a series of virtual monologues. His formerly idealized champion is dying because he would not be a hero, and he himself will die because he could not move Germanicus to take up the calling. Germanicus replies mildly that no one person is the cause of his death, but Time itself: "Nie jy, nie Livia, nie Plancina ... / ek sterf aan hierdie tyd" ("Not you, nor Livia, nor Plancina ... / I'm dying of this time") (p.113).

15 The unusual Afrikaans word "artiest", with its heavily negative overtones, cannot be translated as "artist".

16 This aspect does not warrant further discussion here. It may be seen as an instance of the type of clash between the republican system which Augustus had pretended to restore, and the imperial system, of which Germanicus was the heir-apparent. The areas of authority of the representatives of the old and new systems had not yet been sufficiently clearly defined.

17 Tacitus reports use of a formal letter, Ann. 2.70. Loss of imperial friendship had become a virtual 'kiss of death' since Cornelius Gallus, late prefect of Egypt, lost favour with Augustus in about 26 B.C.

18 Thorough analysis of this facet would entail an essay of its own. This is a creative interpretation of the era which would have had no basis in the consciousness of the historical figures concerned. According to Conradie (1966:23) it should not be over-emphasized in judging the drama. 
He does not explain further than this. He is a passive looker-on, both of his own death and of the changing world. ${ }^{19}$ Agrippina enters and threatens Piso with revenge: "Jy mag nie sterwe sonder pyn" ("You may not perish without pain!") (p.115).

Vengeance will be her "child", she says. Germanicus has the last, apparently flaccid, word in what Antonissen has called the "sublime dispute":

Gaan nou maar, Piso. Ons sal nie eintlik groet nie.

Piso off. (He turns to Agrippina:)

Nou word dit sterftyd, liefste. Ek was lief

vir jou. Laat hul my dra, na binne.

En dalk gaan niks verlore nie.

(Go now, please, Piso. This is not really parting.

Piso off. (To Agrippina:)

And now it's time to die, dear. I loved you

dearly. Let them now carry me inside.

And maybe nothing will be lost.) (pp.115, 116)

Right to the end his cosmic speculations appear of more importance to Louw's Germanicus than the end of a friendship, or even than the parting with his wife. The old doctor, by implication the real murderer, makes the final pronouncement: " $\mathrm{Hy}$ is al by die Caesars" ("By now he's with the Caesars") (p.116).

There are two dominant themes in the drama. First, by means of intelligent reconstruction of hints given by the ancient historians, and imaginative re-creation of conversations that, in the tradition of the speeches we find in such authors, portray what might have been said, Louw presents us with a picture of the conflicting claims within any society of the need for orderly rule, and the loss in the ruler of essential human values, resulting from a clash between his sense of humanity and his desire for power. Second, Louw's Germanicus as a drama reflects his own creatively imaginative interpretation of the end of an era and the dawning of another. Germanicus' prophetic adumbration (in A.D. 19, before the most conservatively reckoned date of the public career of Christ) of the changes to be wrought in the world order by the coming of Christ, is, to the literal-minded, a chronological impossibility. We must accept that Louw, in creating his work of art, chose this era as a vehicle for putting forth his own interpretation of the sweep of history, with the hind-sight of close on two thousand years. Yet Louw's large interpretation of human history we may ignore for the purposes of the present article. Our interest lies in his interpretation of character.

So we must consider the characters of the three male protagonists as portrayed by Louw. We have to do with three levels of characterization: the historic

19 In this Louw deviates widely from Tacitus' version, where amid lamentation Germanicus denounced Piso and Plancina and called for revenge (Ann. 2.69). Schunk (1955:131-134) considers that Tacitus intended with this episode to suggest the essential guilt of the Caesars, where Piso, too, has become "ein Opfer des Tiberius". 
personages as they really were, about whose true natures we can merely speculate, Tacitus' (and Suetonius') constructs of these personages, and Louw's imaginative reconstruction, based more or less loosely on his reading of the ancient authors. We have seen that both Louw's Tiberius and his Germanicus exhibit an historic awareness impossible to the real historic personages, unlikely in Tacitus' Tiberius and improbable in his Germanicus. Tiberius' awareness in Scene Six of the inevitability of acceding to a system tainted by the corruption of absolutism, and his drunken complicity with the unavoidable, are plausible when considered in the light of the hints given by Tacitus about Tiberius' reluctance to take power (Ann. 1.6-10) and Suetonius' portrait of a man haunted.

Louw's Germanicus initially appears unaware of the forces involved in the exercise of power, both the inevitability of corruption through its absolute exercise and the potential of the masses to force a ruler to act against his better instincts. In the pivotal sixth scene Tiberius spells out to his adopted son that withdrawal is impossible: if the younger man were to retire to a private life, he would become the notional leader of every rebellious faction within the empire (cf. Brink 1959:60). There is no way to withdraw, and there is no means to rule well, to remain true to a conception of purity and clarity:

Waar almal dronk is, self wil nugter bly ... dít word die waansin.

(Where all are drunk, to stay stone sober still ... therein lies madness.) (p.73)

So Louw's Tiberius chooses drunken acquiescence; his Germanicus bows to a new inevitability: notwithstanding his desire for clarity and purity, he is part of the system. The only escape lies in death. He becomes a willing victim. He remains the representative of light and order, but cannot combat the powers of darkness and chaos. Yet Louw's Germanicus, the seeker after clarity, the man of light who must fight against the chaos around him, and his swart Piso ("black Piso"), the harker-back to a lost republican system, cannot simply be judged as protagonist and antagonist, good against evil and light against darkness. Piso stands for another type of simplicity, and Germanicus carries the seeds of darkness within himself.

Louw has built up a character for Piso from mere hints given by Tacitus. It may be that his characterization of Cnaeus Piso as republican leans in part on the staunchly independent Lucius Calpurnius Piso of $A n n$. 2.32-35, who showed spirit in denouncing official malfeasance in the courts, threatening to withdraw from the corruption of public life, in prosecuting a friend of Livia Augusta in the face of opposition from Tiberius, and in insisting that the Senate did not require the presence of the emperor in order to transact its business (cf. Syme 1970:51-55). Mendell's article showing Piso as one of the representatives of libertas may well have influenced an author well-versed in classical scholarship. ${ }^{20}$ But Louw's Piso is

20 Cf. Van Rensburg 1990, also the fact of Ovidian influence in Louw's Tristia. 
essentially a construct: black Piso, the representative of darkness, whose initial friendship with Germanicus Louw portrays in warmer terms than the ancient Roman practice of amicitia (often no more than a temporary political alliance) might have warranted. Amicitiam renuntiare could often mean no more than a severing of political ties. ${ }^{21}$ When the historical Germanicus did so (Ann. 2.70), he was creating a political chasm between himself, the representative of the emperor, and a recalcitrant subject. Louw does, however, build up a plausible picture of Piso as a simple-minded military man whose views of black and white can admit no shades of grey, while at the same time allowing for the possibility of another interpretation, that Plancina was Livia's instrument and that Piso became a murderer only by default when he became aware of both his hero's frailty and his wife's treachery. The final scene of quasi-reconciliation. is historically unlikely, but artistically satisfactory. Piso, too, is the victim of a changing era, and he, too, was doomed not to do otherwise than he did.

Germanicus becomes resigned to participation in the chaos that imperial rule brings to many lives; the soldierly Piso wants a return to greater simplicity, to an order where every Roman had a fixed role and was bound by obligation to his peers. Perhaps the best interpretation, and one I have not read in other critics, is that Louw's two characters together represent the tortured man that is the Tiberius portrayed by Tacitus and Suetonius. Tiberius was an upright and efficient soldier, the son of a staunch republican, who once sought to withdraw to a simpler life of study, but was doomed to a grudging adoption into a system of which he, as we may deduce from Tacitus' representation of his unwilling acceptance (Ann. 1.11, 12), did not approve. His second and final withdrawal from the seat, but not the wielding, of power followed after the events with which the drama closes. Louw's drama, together with Jonson's, gives us the 'Tragedy of Tiberius' discemed by Mendell (1935) within Ann. 1-8.22

The three women are similarly matched, each as foil to one of the male figures, but in the end also creating a composite. Agrippina as the strong and loyal wife whose support made Germanicus' wielding of power possible can be seen as a type, representing what is good in Livia, the 'good mother' Livia, planning to promote the career of her son. Plancina, the purveyor of poison, whose loyalty to Livia is greater than to her husband's republican idealism, is a younger edition of Livia die ou apie ("the old monkey") (p.54), ${ }^{23}$ ready to do whatever is vile for the sake of unspecified

21 Hellegouarc'h 1963: s.v. amicitia.

22 A detailed comparison between Louw and Jonson in their depiction of Tiberius is uncalled-for here, but to the extent that they agree, we may consider both true to the elements common to Tacitus and Suetonius in their depiction of the emperor, but not in Velleius Paterculus, whose portrait is far more sympathetic. Cf. Ayres 1990:28-37; Conradie 1974.

23 The German captive Thusnelda serves to illuminate aspects of the Roman women's characters. Livia maltreats her, Agrippina is kind. In Scene Five, when Livia forces Plancina to stand next to Thusnelda, the Roman woman is indicated as being physically of small stature, with the implication, too, of a moral lack. 
gain. Significantly, in the scenes in which Agrippina and Livia converse with their respective male counterparts, a dimension of each male character is highlighted (cf. Brink 1959:74-75), but Plancina and Piso, while attending the Nabatean banquet together, hardly exchange a word. Piso only indirectly defends his wife against Agrippina's accusation of poison, and then remains silent (p.94), whereas Plancina appears as another opponent of her husband in her spirited defense of the imperial reputation. Here Plancina sees herself as the representative of both Tiberius and Livia:

Sy tas die majesteit van Caesar aan waar sy sy moeder noem, en sò;

jy sal nog weer in Rome trug moet kom!

(She hurts the majesty of Caesar when

she talks about his mother-so;

you know you must go back to Rome again!) (p.95)

After this, she does not reappear. In the final scene, Piso attests to his former willingness to repudiate her and to have stopped the course of the poison, if only Germanicus had acceded to his attempts to rally him to the republican cause-and thereby to be true to the 'greatness' within him (p.112). Neither Plancina nor Livia was causing the hero's death, but Piso's love, which had turned to hatred, because Germanicus had chosen to remain mundane:

jy weet nie hoe jy my verneder het toe jy nie gròdt wou wees-toe jy ... gewoon was.

(You do not know how much you brought me down when greatness was thrust back-when you ... chose tameness.) (p.112)

Louw has contracted and conflated the action of the years 16 to 19 A.D., Ann. 1619 , in which Tacitus relates the further quasi-rebellious actions of Piso. Louw does not continue with Piso's trial and subsequent suicide (Ann. 3.7-19.2). These events are reflected in the Senatusconsultum de patre Pisone. Werner Eck, one of the editors of the Senatusconsultum, complains elsewhere (1993b) about the paucity of material usually available for historical research. For him the discovery of the document was no doubt a godsend. For the literary critic the uncomfortable thought arises: Here at last we have an historic document focusing on a character which has been constructed by our dramatist. Will it prove our dramatist wrong-or inadequate, brash and fanciful?

First we need to study the gist of the Senatusconsultum, which was apparently published in four columns of between 40 and 45 lines each. ${ }^{24}$ Its prescript lists the

24 Protocol forbids quotation from the text, which has not yet been published in full, and so for this passage I am relying on Eck's analysis (1993a). 
official witnesses to the document and Tiberius' authority for its publication. ${ }^{25}$ This is followed by a short relatio: Tiberius' injunction to the Senate to consider the circumstances which led to the death of Piso and the subsequent request by his wife and son for restitution of their property. Two of Piso's companions were also brought under scrutiny. The gods and Tiberius are thanked for the peaceful outcome of the matter, after which follows a long description (48 lines) of Piso's conduct, as reported to the Senate, ${ }^{26}$ and the Senate's judicial decisions relating to the accused. Eck (1993a:194) emphasizes that only once, in the preamble, is Germanicus' death blamed directly on Piso. That Germanicus himself associated his end with Piso's machinations receives due emphasis as the ground for the formal renuntiatio amicitiae. Further accusations relate, as in Tacitus, to Piso's undermining of Germanicus' decisions and authority, and his conduct of wars in the East against the mandates of both Tiberius and Germanicus. His indiscipline, amounting to civil war, after the death of Germanicus, is given as another count. Worse, his exhibition of unalloyed joy after the death of the prince is indicted, 27 and an accusation against Germanicus, relayed to Tiberius after the death of the former, is listed as evidence of wrong-doing on the part of its author. His death at his own hand was seen as "robbing the Senate of its just revenge". Strict injunctions against any signs of mourning to be exhibited by Piso's family and close friends were added to an order that his own statues be pulled down and his name be erased from inscriptions on the monuments of others. Some of his possessions, gifts by Augustus, were to revert to the imperial family, and one of his buildings was to be pulled down, but for the rest clemency was to be extended toward his children and wife, against whom no accusations would stand. Even the younger son, who had been in Syria at the time of Germanicus' death, received no blame, and provision would be made for dowries for both his daughters. The Senate acknowledged Tiberius' lead in these decisions.

About Plancina: the document admits that there had been serious charges against her, but that in acknowledgement of Livia Augusta's great service to the state in producing her great son Tiberius, all charges were to be dropped against her favourite, without further specification of reasons. Eck (1993a:199) comments that the stark relaying of an obviously tendentious decision is clear evidence of tremendous tension within the Senate and the difficulties experienced by both Senate and emperor simply to remit accusations against Plancina: "Die Grunde für die Begnadigung haben nichts mit der Person Plancinas, wenig mit Tiberius, aber alles mit Livia zu tun." In contrast, Piso's two friends, Visellius Carus and Sempronius Bassus, were to be prosecuted to the utmost severity of the law of interdictio aqua et igni, including sequestration of their assets.

25 Eck (1993a:208 n.89) points out that Tiberius merits twenty-nine references in the document, and earlier he shows (p.202) that Tiberius' moderatio is stressed. Cf. Christes 1994 on Tacitus' dismissal or denigration of the term in relation to Tiberius.

26 This largely concurs with $A n n .2 .55,57$ and 69-70.

27 As related by Tacitus, Ann. 2.75.2-77. 
Then follows a laudatio of the house of Augustus and its members individually: Tiberius, Livia and Drusus Minor for pietas exhibited to the late Germanicus, Agrippina for her holy life with the martyr, his mother Antonia for her exemplary life, and his sister Livia, of whom her grandmother and great-uncle had approved a marital alliance within the family (to another Drusus). The grief of the martyr's children and his brother is praised for not overstepping the bounds of moderation. The House's thanks to the various orders, with a hope that no military emulator of Piso's misdeeds will appear and an affirmation of the ascendence of the Caesarian name in military loyalties, are followed by a note on the decision to publish the Senatusconsultum in Rome, all the provinces and in each legion's military fane. The document ends with a personal attestation by Tiberius and the date. Eck (1993a:208) comments that in spite of the superscription Senatusconsultum de Cn Pisone patre, the real focus of the document is Tiberius himself, and Tiberius as princeps noster: "first and leader of all 'we' (the Senate) do". The question remains, does it cast a light that differs from the shades adumbrated by Tacitus around these and other figures, which were picked up and extended by our dramatist?

Tacitus implies (Ann. 2 69-70) that Piso and Plancina were both involved in Germanicus's death. Certainly Plancina outdid her husband's transports of joy at the death of the prince, and she chose at that time to put off the mourning she had been wearing for a sister, to change into festive garments. It would appear that the exoneration of Plancina from all blame and its implication of a profound division between husband and wife is the only major difference between the Senatusconsultum and Tiberius' narrative of the events of October A.D. 19. Tacitus' account of the trial shows that Piso's defense could not refute the charges of bribery of the troops and insurrection against his commander, but that the charge of poison remained unsubstantiated. Plancina remained loyal to him until it became clear that he could in no way save himself, after which she conducted a separate-and more successful-defense. Tacitus hints strongly that Piso did have an injunction from Tiberius to do away with Germanicus, but admits that he cannot substantiate the assertion. ${ }^{28}$ Tiberius himself admitted as evidence Piso's exoneration of his children, but of Plancina "nothing was said". Tacitus relates the obvious embarrassment with which Tiberius cited his mother's entreaties as the ground for Plancina's defense. The tone of the Senatusconsultum on this point agrees very well with Tacitus' account.

The salient question is, however, whether the Senatusconsultum gives the kind of detail that would have prompted Louw, at the time of composition, to have worked out a different plot for his drama. Does the character of Piso as Louw constructed it from Tacitus' narrative of his deeds still hold? Is Louw's portrayal, as intelligent guesswork, supported by these new insights? Again we must emphasize that in Germanicus we have to do with a creative and imaginative poet's choice to

28 Martin (1994:123) reckons that Tiberius' studied impartiality may be considered either as a refusal to support his own nominee or, conversely, to seek retribution. 
propound a timeless human problem within a specific historical framework, as it was set out by another creative and poetic master of language. We have seen that Louw's portrayal of his Piso's loyalty to the republican ideal, initially shared by his Germanicus, works within the general critical interpretation of Tacitus' intention with the more limited (in the case of Piso) and more detailed (in the case of Germanicus) portrayal of these two characters. Louw's picture of gradual disaffection between the two men helps to give greater consistency and to smooth out the discrepancies inherent in Tacitus' problematic portrayal of a Piso both defender of libertas, and instrument of Tiberius. Louw's Germanicus is something more than the popular but problematic prince that emerges from a first, cursory reading of Annales 1 and 2 . His portrait of an intellectual, doomed by his own historical awareness to inactivity, is not wholly Tacitean, but gains in credibility when Germanicus' known dedication to the arts is remembered (including his poetic reworking of Aratus' treatise on astronomy).

Louw's greatest contribution to a rounded picture of the affair is, however, his recreation of the tangled intrigues of Livia and Tiberius and his projection of a Plancina disaffected from her republican husband at a much earlier stage than Tacitus allows for. With this portrayal the exoneration of Plancina as spelled out in the Senatusconsultum is wholly consistent. N.P. Van Wyk Louw's historical sense emerges in his interpretative reading of the facts at Tacitus' disposal in a more consistent and possibly more satisfactory way than that of his ancient predecessor. Had he had the Senatusconsultum de Pisone patre at his disposal at the time of his composition of Germanicus, I do not believe that he would have changed one word. His genius lies in the poetic sensibility with which he arranged these words.

\section{BIBLIOGRAPHY}

Antonissen, R 1962. Kern en tooi: Kroniek van die Afrikaanse lettere 1951-1960. Cape Town: Nasou.

Ayres, P (ed.) 1990. Ben Jonson: Sejanus, His Fall. Manchester and New York: Manchester Univ. Press.

Bauman, R A 1994. Tanaquil: Livia and the Death of Augustus. Historia 43(2), 177-188.

Billerbeck, M 1991. Die Dramatische Kunst des Tacitus. ANRW II.33.4, 27522771.

Brink, A P 1959. Germanicus en die tragedies van Shakespeare. M.A. thesis, Potchefstroom.

Christes, J 1994. Tacitus und die moderatio des Tiberius. Gymnasium 101, 112135.

Cizek, E 1993. Autour de Tacite. RCCM 35(2), 219-244.

Conradie, P J 1966. N.P. Van Wyk Louw: Germanicus. Pretoria: Academica.

Conradie, P J 1972. Beeldspraak in Germanicus. Tydskrif vir Letterkunde 10(3), 3038. 
Conradie, P J 1974. Die gebruik van antieke bronne in Van Wyk Louw se Germanicus. In Spanning en ewewig. Pretoria: Academica.

Devillers, $O$ 1993. Le rôle des passages relatifs à Germanicus dans les Annales de Tacite. Ancient Society 24, 225-241.

Eck, W 1993a. Das s.c. de Cn. Pisone Patre und seine Publication in der Baetica. Cahiers du Centre Glotz 4, 189-208.

Eck, W 1993b. Überlieferung und historische Realität: Ein Grundproblem prosopographischer Forschung. In Eck 1993c, 363-396.

Eck, W 1993c. Prosopographie und Sozialgeschichte. Kolloquium Koln, 24-26 November 1991. Köln: Böhlau.

Fabbrini, F 1986. Tacito tra storiografia e tragedia. In I raconti di Clio. Tecniche narrative della storiografia. Pisa (La Porta di Corno 6.)

Furneaux, H (ed.) 1915. Corneli Taciti Annalium. Oxford: Clarendon.

Grové, A P 1965. Oordeel en vooroordeel. New ed. Cape Town: Nasou.

Hellegouarc'h, J 1963. Le vocabulaire latin des relations et des partis politiques sous la République. Les Belles Lettres: Paris.

Kannemeyer, J C 1978. Geskiedenis van die Afrikaanse literatuur. Pretoria: Academica.

Koves-Zulauf, Th. 1992. Reden und Schweigen in Taciteischen Dialogus de oratoribus. Rheinisches Museum 135, 316-341.

Louw, N P Van Wyk 1956. Germanicus. Cape Town: Tafelberg.

Luce, T J \& Woodman A J (edd.) 1993. Tacitus and the Tacitean Tradition. Princeton: Princeton University Press.

Martin, R 1981. Tacitus. 2nd ed. Bristol Classical Press.

Mendell, C W 1935. Dramatic Construction of Tacitus' Annals. Yale Classical Studies 5, 3-53.

Moog, F P 1992. Germanische Erziehung bei Tacitus: Rom vor dem Hintergrund germanischer Geschichte. Bonn: Peter Wegener.

Muller, L 1994. La mort d'Agrippine (Tacite Annales 14.1-13): Quelques elements tragiques de la composition du récit. Les études classiques 62(1), 27-43.

Olivier, G 1992. N.P. Van Wyk Louw: Literatuur, filosofie, politiek. Cape Town: Human \& Rousseau.

Pelling, C 1993. Tacitus and Germanicus. In Luce \& Woodman 1993, 59-85.

Petersmann, G 1993. Fiktionalisienung von Fakten: Kompositionsstrukturen als Fiktionalitätssignale bei Sallust und Tacitus. Altsprachliches Unterricht 36(1), 8-18.

Piek, C J 1971. Die katarsis-belewing in Germanicus van N.P. Van Wyk Louw. M.A. thesis, UNISA.

Pretorius, R 1972. Die begrip 'intellektueel' by N.P. Van Wyk Louw. Pretoria: Van Schaik.

Ross, D O 1973. The Tacitean Germanicus. Yale Classical Review 23, 209-227.

Santoro L'Hoir, F 1994. Tacitus and Women's Usurpation of Power. Classical World 88(1), 5-25. 
Schunck, P 1955. Römisches Sterben: Studien zu Sterbeszenen in der kaizerzeitlichen Literatur, insbesondere bei Tacitus. Diss. Heidelberg.

Shotter, D C A 1968. Tacitus, Tiberius and Germanicus. Historia 17, 194-214.

Spath, T 1994. Männlichkeit und Weiblichkeit bei Tacitus. Frankfurt: Campus Verlag.

Strocchio, R 1992. I significati del silenzio nell' opera di Tacito. Memoria dell' Accademia delle Scienze di Torino, 3-48.

Syme, R 1958. Tacitus. Oxford: Clarendon.

Syme, R 1970. Ten Studies in Tacitus. Oxford: Clarendon.

Van Rensburg, F I J 1990. 'n Afrikaanse Abelard en Heloise. The South African Journal of Medieval and Renaissance Studies 1(1), 1-17.

Velaza, J 1993. Tacito y Augusto (Ann.I.9-10). Emérita 61, 335-356.

Wille, G 1983. Der Aufbau der Werke des Tacitus. Amsterdam.

Wiseman, T P 1994. Historiography and Imagination. Exeter: Exeter Univ. Press. 